\title{
NUTRITIONAL BENEFITS OF Bifidobacterium lactis IN DAIRY PRODUCTS
}

\author{
Ilze Beitāne and Inga Ciproviča \\ Faculty of Food Technology, Latvia University of Agriculture, Lielā iela 2, Jelgava, LV-3001, LATVIA; \\ Ilze.Beitane@ @lu.Iv
}

Communicated by Edīte Birǵele

\begin{abstract}
Bifidobacteria are one of the most important probiotics in dairy products. They have positive effects on human health. Nutritional benefits of bifidobacteria are genetically determined and can be promoted with addition of prebiotics. The aim of the present study was to examine the properties of Bifidobacterium lactis in dairy products. Pasteurised milk, freeze-dried starter culture Bb-12 (Bifidobacterium lactis, Chr. Hansen, Denmark), syrup of lactulose (Duphalac ${ }^{\circledR}$, the Netherlands), and inulin ("Raftiline ${ }^{\circledR} H P$ ", ORAFI, Belgium) were used in the experiments. The optimal concentrations of lactulose (2\%) and inulin (4\%) were established in preliminary studies, based on quality indices and nutritional value of fermented dairy products (Beitane, 2008). Amino acids, carbohydrates, such as lactose, lactulose and inulin, as well as cholesterol were determined during the study using appropriate analytical procedures. The enzymatic activity of bifidobacteria determines nutritional value of the fermented dairy products. Addition of $2 \%$ lactulose resulted in significant increase of some amino acid concentrations, such as leucine, phenylalanine, lysine and arginine concentrations $(\mathrm{P}<0.05)$, compared with those in other treatments. The presence of prebiotics caused a decrease of cholesterol level by $35 \%$ and lactose content by $31 \%$ in fermented milk samples. The enzymatic activity of bifidobacteria should be promoted with addition of lactulose and inulin to increase nutritional value of functional dairy products.
\end{abstract}

Key words: bifidobacteria, lactulose, inulin, lactose, amino acids, cholesterol.

\section{INTRODUCTION}

Bifidobacteria are one of the most important probiotics in dairy products (Parvez et al., 2006; Russell et al., 2011). Probiotics are live microorganisms which when administered in adequate amounts confer a health benefit on the host (Oliveira et al., 2011). Bifidobacteria have positive effects on human health: (1) synthesis of vitamins (Crittenden et al., 2003; Beitane and Ciprovica, 2011); (2) immunostimulation (Dong et al., 2010); (3) cholesterol reduction (Ziarno et al., 2007; Beitane, 2008); (4) lactose hydrolysis (He et al., 2007); and (5) prevention of infectious diarrhoea (Qiao et al., 2002). Nutritional benefits of bifidobacteria are genetically determined. Bifidobacteria are saccharolytic and produce organic acids (Russell et al., 2011). They release various enzymes, such as leucine, valine and cystine aminopeptidases, $\alpha-, \quad \beta$-galactosidases, $\alpha, \quad \beta$-glucosidases, $N$-acetyl- $\beta$-glucosaminidase, esterases during multiplication (Martinez-Villaluenga and Gomez, 2007), which improve nutritional value of the end product: higher content of amino acids, and lower content of cholesterol and lactose in fermented dairy products. Thereby milk products are acceptable for patients with hypercholesterolemia and lactose intolerance. The growth of bifidobacteria can be promoted with addition of prebiotics (Rastall and Maitin, 2002).

Prebiotics are non-digestible food ingredients that beneficially effect the host by selective stimulating the growth and/or activity of one or a limited number of bacteria in the colon (De Vrese and Schrezenmeir, 2001). Lactulose and inulin are one of the widely used prebiotics for promotion of bifidobacteria growth in milk and the gastrointestinal tract (Szilagyi et al., 2001; Palframan et al., 2002; Holzapfel and Schillinger, 2002; Aider and de Halleux, 2007; Bouhnik et al., 2007). Lactulose is mostly used in Europe, Japan and the United States (Tuohy et al., 2005). It is a synthetic disaccharide created by the isomerisation of lactose (Aider and de Halleux, 2007). Fructo-oligosaccharides are widely used as commercial prebiotics, which contain a varying number of fructose monomers connected by $\beta$-2-1-glycosidic bonds (Russell et al., 2011). Evaluation of the suitability of prebiotics for promotion the growth of bifidobacteria in milk showed that the appropriate concentration were 2\% lactulose and 4\% inulin (Beitane and Ciprovica, 2008). The aim of the present study was to examine the specific properties of Bifidobacterium lactis in dairy products. 
Pasteurised milk with fat content $2.5 \%$ and freeze-dried Bifidobacterium lactis culture (Bb-12, Chr. Hansen, Denmark) were used for the experiments. During the experiments, the culture was maintained at $-18{ }^{\circ} \mathrm{C}$. As additions, the following prebiotics were used: inulin "Raftiline ${ }^{\circledR} \mathrm{HP}$ " (ORAFI, Belgium) with polymerization degree $\geq 5$ and degree of purity $99.5 \%$ and syrup of lactulose (Duphalac ${ }^{\circledR}$, the Netherlands) with the following composition (\%): lactulose - no less than 67 , lactose - less than 6 , galactose - less than 10 .

$2 \%$ lactulose and 4\% inulin were added individually to 100 $\mathrm{g}$ of milk. The concentrations of prebiotics were chosen according to previous study, in which the optimal bifidogenic effect of lactulose and inulin was established (Beitane and Ciprovica, 2008). Bifidobacterium lactis was inoculated with $2 \mathrm{ml}$ of milk suspension $\left(10^{6} \mathrm{cfu} \mathrm{m}^{-1}\right)$ and cultured at $37{ }^{\circ} \mathrm{C}$ for 16 hours. The control sample was prepared without prebiotics for comparison.

The content of amino acids was determined with an automatic amino acids analyser AAA 339 (Microtechna Praha, Czech Republic), according to requirements of „Amino acid standard solution for protein hydrolysates $-0.5 \mu$ moles per ml".

The level of cholesterol was determined according to AOAC Official Method 976.26A.

The concentrations of lactose and lactulose were determined by IDF standard 147B:1998 procedure, the content of inulin by AOAC Official Method 999.03 and by AACC Official Method 32.32.

Significant differences were determined by analysis of variance (ANOVA) and t-tests at $P$ value 0.05 .

\section{RESULTS}

The concentrations of amino acids in milk, control and fermented milk samples with $2 \%$ of lactulose and $4 \%$ of inulin are shown in Table 1.

The obtained results showed that the addition of lactulose increased amino acid concentration in fermented product more than with inulin; the highest total amino acids after fermentation in fermented dairy product was $2.829 \mathrm{~g}$ $100 \mathrm{~g}^{-1}$.

ANOVA indicated significant increase of isoleucine, leucine and lysine concentrations $(P<0.05)$ in fermented milk with $2 \%$ of lactulose, compared with other treatments. A significant decrease of leucine, phenylalanine, lysine and arginine concentrations $(P<0.05)$ were observed in fermented milk with $4 \%$ inulin, indicating promotion of glycolysis and suppression of proteolysis in fermented milk with $B$. lactis. Lactulose facilitated the proteolytic properties of bifidobacteria.
CONCENTRATIONS OF AMINO ACIDS IN FERMENTED MILK SAMPLES WITH LACTULOSE AND INULIN, g $100 \mathrm{~g}^{-1}$

\begin{tabular}{l|c|c|c|c}
\hline \multicolumn{1}{c}{ Amino acids } & Milk & Control & $\begin{array}{c}\text { Fermented } \\
\text { milk with 2\% } \\
\text { of lactulose }\end{array}$ & $\begin{array}{c}\text { Fermented } \\
\text { milk with 4\% } \\
\text { of inulin }\end{array}$ \\
\hline Threonine & 0.107 & 0.095 & 0.112 & 0.094 \\
Valine & 0.130 & 0.115 & 0.123 & 0.101 \\
Methionine & 0.061 & 0.064 & 0.075 & 0.052 \\
Isoleucine & 0.095 & 0.087 & 0.108 & 0.078 \\
Leucine & 0.254 & 0.232 & 0.271 & 0.207 \\
Phenylalanine & 0.115 & 0.114 & 0.093 & 0.095 \\
Tyrosine & 0.131 & 0.123 & 0.121 & 0.094 \\
Lysine & 0.197 & 0.181 & 0.208 & 0.151 \\
Aspartic acid & 0.233 & 0.212 & 0.223 & 0.201 \\
Serine & 0.133 & 0.115 & 0.154 & 0.109 \\
Glutamic acid & 0.620 & 0.569 & 0.711 & 0.366 \\
Proline & 0.248 & 0.221 & 0.277 & 0.178 \\
Glycine & 0.051 & 0.039 & 0.052 & 0.044 \\
Alanine & 0.086 & 0.069 & 0.094 & 0.073 \\
Histidine & 0.100 & 0.108 & 0.108 & 0.108 \\
Arginine & 0.089 & 0.092 & 0.099 & 0.087 \\
Total & 2.650 & 2.436 & 2.829 & 2.038 \\
& & & &
\end{tabular}

The ability of $B$. lactis to assimilate cholesterol during milk fermentation in the presence of prebiotics was studied. The levels of cholesterol in milk, control and in fermented milk samples with $2 \%$ of lactulose and $4 \%$ of inulin are presented in Figure 1.

The results showed that fermentation of milk with $B$. lactis decreased cholesterol concentrationt by $25 \%$ in samples, indicating promotion of this activity by prebiotics. Both prebiotics showed similar results. Significant differences were observed between milk and fermented milk samples with and without prebiotics $(P<0.05)$. Differences between control and fermented milk samples with prebiotics were insignificant $(P>0.05)$.

The lactose concentrations in samples with and without prebiotics before and after fermentation are presented in Figure 2. Decrease of lactose concentration during fermen-

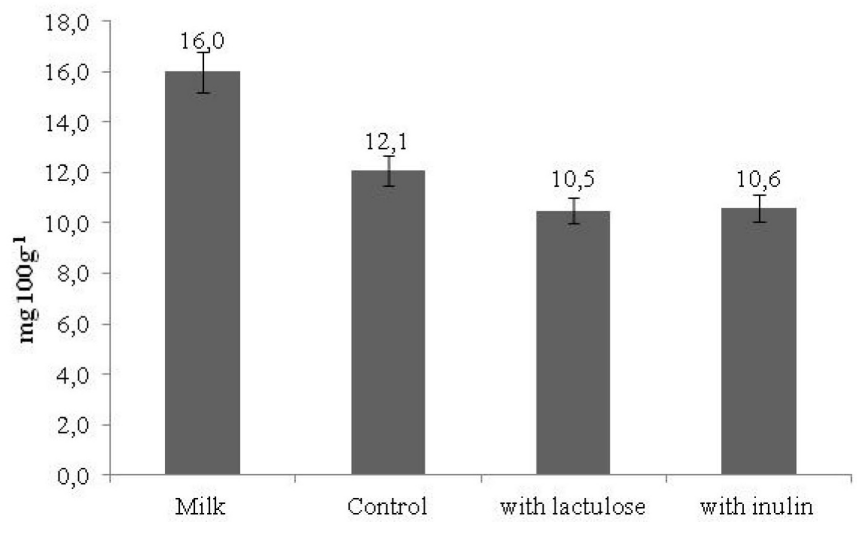

Fig. 1. Level of cholesterol in milk, control and in fermented milk samples with $2 \%$ lactulose and $4 \%$ inulin. 


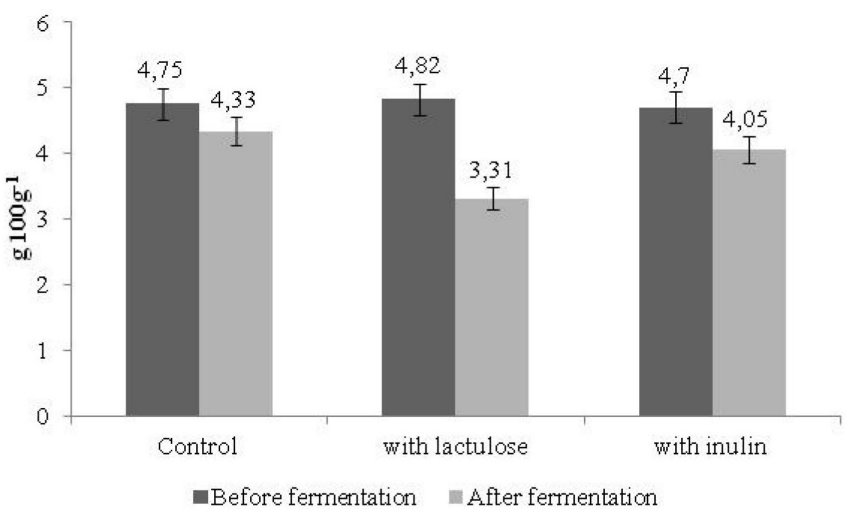

Fig. 2. Concentration of lactose in milk before and after fermentation with and without prebiotics (increasing of lactose content in milk samples before fermentation is associated with the presence of lactose in lactulose syrup).

tation occurred in all samples. The highest reduction of lactose content was observed in samples with $2 \%$ lactulose, i.e.

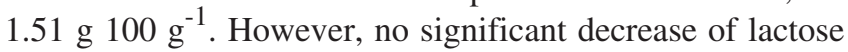
were established $(P>0.05)$ between fermented milk sample with $2 \%$ lactulose and other fermented milk samples with prebiotics. Changes of lactose content during fermentation in samples with and without prebiotics were significant $(P<$ $0.05)$.

Regarding the ability of $B$. lactis to hydrolyse with addition of prebiotics, the results showed that bifidobacteria have the ability to ferment up to $50 \%$ of added lactulose (from $1.34 \mathrm{~g}$

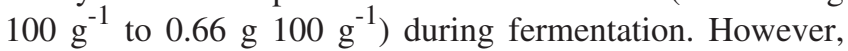
the decrease of inulin concentration was negligible (from

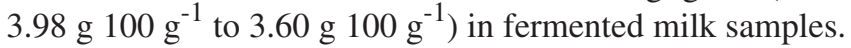
In the present study, inulin with a polymerisation degree $\geq 5$ and degree of purity $99.5 \%$ was used, which could explain the obtained results.

\section{DISCUSSION}

The growth of the starter bacteria in milk depends on their proteolytic activity to hydrolyse casein (Thomas and Mills, 1981), where casein is the main source of amino acids in milk (Walstra et al., 2006). It is known that proteolytic properties of bifidobacteria are quite weak (Sgorbati et al., 1995), however, they release aminopeptidases during multiplication (Martinez-Villaluenga and Gomez, 2007). They are vital for metabolic pathway regulation, cell maturation and protein turnover (Herrera-Camacho et al., 2007). Much research indicates that bifidobacteria are able to synthesise a considerable amount of amino acids (Matteuzi et al., 1978; Ballongue, 2003), which is in contrast with the present results. Regarding concentrations of amino acids in milk and control (Table 1), there was a decrease of amino acid concentrations, except histidine and arginine, in fermented milk samples. However, B. lactis has the ability to synthesise a remarkable amount of specific amino acids, such as threonine, methionine, tyrosine, lysine and aspartic acid, compared with lactic acid bacteria (Table 2). The differences of amino acids concentration in milk and fermented
CONCENTRATIONS OF AMINO ACIDS IN FERMENTED MILK SAMPLES USING DIFFERENT STARTER CULTURES, g $100 \mathrm{~g}^{-1}$

\begin{tabular}{l|c|c|c|c}
\hline Amino acids & B. lactis & $\begin{array}{c}\text { L. lactis } \\
\text { C15 }\end{array}$ & $\begin{array}{c}\text { L. bulgaricus } \\
\text { HP1 }\end{array}$ & $\begin{array}{c}\text { L. helveticus } \\
\text { MP12 }\end{array}$ \\
\hline Threonine & 0.095 & 0.005 & 0.035 & 0.011 \\
Valine & 0.115 & 0.096 & 0.138 & 0.092 \\
Methionine & 0.064 & 0.006 & 0.040 & 0.048 \\
Isoleucine & 0.087 & 0.003 & 0.254 & 0.144 \\
Leucine & 0.232 & 0.037 & 0.266 & 0.297 \\
Phenylalanine & 0.114 & 0.092 & 0.142 & 0.294 \\
Tyrosine & 0.123 & 0.022 & 0.022 & 0.020 \\
Lysine & 0.181 & 0.006 & 0.074 & 0.036 \\
Aspartic acid & 0.212 & 0.032 & 0.041 & 0.161 \\
Serine & 0.115 & 0.061 & 0.215 & 0.234 \\
Glutamic acid & 0.569 & 0.677 & 1.130 & 2.051 \\
Proline & 0.221 & 0.202 & 1.007 & 1.281 \\
Glycine & 0.039 & 0.032 & 0.057 & 0.158 \\
Alanine & 0.069 & 0.093 & 0.454 & 0.543 \\
Histidine & 0.108 & 0.050 & 0.174 & 0.232 \\
Arginine & 0.092 & 0.007 & 0.094 & 0.024 \\
Total & 2.436 & 1.421 & 4.143 & 5.465 \\
& & & &
\end{tabular}

After Simova et al., 2006

milk can be explained by the need of amino acids for bifidobacteria growth (Ballongue, 2003).

B. lactis can release high activity leucine and valine aminopeptidases (Martinez-Villaluenga and Gomez, 2007). This can be explained by the chemical composition of milk, method of preparation and storage conditions of experimental samples. We observed an increase of aminopeptidase activity by addition of $2 \%$ lactulose, which led to a significant increase $(P<0.05)$ of isoleucine, leucine and lysine. Amino acids released by bifidobacteria influenced the nutritional value of fermented products.

Bifidobacteria can decrease the serum cholesterol in blood (Xiao et al., 2003), which can be promoted by addition of prebiotics (Pereira and Gibson, 2002). The cholesterol-lowering effect of probiotics can be explained by, for example, enzymatic deconjugation of bile acids by bile salt hydrolase of probiotics (Kumar et al., 2012). The decrease of cholesterol concentration in fermented milk in the present study can be explained by the activity of esterases, which was determined as intermediate activity for B. lactis (MartinezVillaluenga and Gomez, 2007). Esterases have the capacity for hydrolysis and synthesis of esters by esterification of fatty acids and ethanol (Liu et al., 2004). Esterases from lactic acid bacteria release preferentially short-chain fatty acids, and furthermore, several strains possess more than one esterase (Oliszewski et al., 2007). The decrease of cholesterol level in milk depends mainly on the bacteria species used for fermentation (Oberman and Libudzisz, 1998). Lactobacillus acidophilus and Bifidobacterium spp. in fermented milk are able to assimilate cholesterol from $18 \%$ to $38 \%$ in fermented milk (Ziarno et al., 2007). The results of 
the present study showed that $B$. lactis can assimilate cholesterol by $25 \%$ in milk, whereas by $35 \%$ with addition of the studied concentrations of lactulose and inulin. Thus, the presence of prebiotics in milk promotes $B$. lactis esterase activity.

Two-thirds of the world's adult population suffers from lactose maldigestion (Vesa et al., 2000), which is caused by reduction of $\beta$-galactosidase activity in the small intestine after weaning (Russell et al., 2011). Jiang et al. (1996) indicated that $\beta$-galactosidase improves lactose utilization for lactose intolerant patients. Martinez-Villaluenga and Gomez (2007) reported that $\beta$-galactosidase activity for mostly bifidobacteria strains was high, but $B$. lactis had intermediate activity. $\beta$-galactosidase is widely employed for reduction of lactose content in milk products (Rhimi et al., 2010), thereby fermented milk products are acceptable for patients with lactose intolerance. Lactose is split by $\beta$-galactosidase into glucose and galactose (Kandler, 1983). The activity of $\beta$-galactosidase released from $B$. lactis can be described as intermediate (Martinez-Villaluenga and Gomez, 2007), which explain the results of the present study. Evaluating the ability of B. lactis to assimilate added lactulose and inulin, it was obvious that lactulose was most suitable substrate for growing of bifidobacteria in milk.

This confirmed the results mentioned in literature about the bifidogenic effect of lactulose in certain concentrations (Palframan et al., 2002; Bouhnik et al., 2004) and the ability of bifidobacteria to assimilate lactulose (Saarela et al., 2003). Semjonovs et al. (2004) reported that B. lactis is not able to assimilate inulin. Biedrzycka and Bielecka (2004) indicated that inulin assimilation decreases the inulin polymerisation degree and the degree of purity.

In conclusion, the enzymatic activity of bifidobacteria determines nutritional value of fermented dairy products. The addition of $2 \%$ lactulose resulted in significant increase of some amino acids, such as leucine, phenylalanine, lysine and arginine $(P<0.05)$, compared with the other treatment. The presence of prebiotics resulted in decrease of cholesterol level by $35 \%$ and lactose content by $31 \%$ in fermented milk samples. The enzymatic activity of bifidobacteria can be promoted by addition of lactulose and inulin to increase the nutritional value of functional dairy products.

\section{REFERENCES}

Aider, M., Halleux, D. (2007). Isomerization of lactose and lactulose production: Review. Trends Food Sci. Technol., 18, 356-364.

Ballongue, J. (2003). Bifidobacteria and probiotic action. In: Salminen, S., Wright, A., Ouwehand, A. (eds.). Lactic Acid Bacteria. Microbiological and Functional Aspects (pp. 67-125). New York: Marcel Dekker, Inc.

Beitane, I. (2008). The evaluation of lactulose and inulin for the development of a new functional milk product. Doctoral dissertation, Latvia University of Agriculture, Jelgava, Latvia. 124 pp.

Beitane, I., Ciprovica, I. (2008). Prebiotics - the influencing factors on growth and survival of probiotics in milk [Prebiotikas - probiotisko baktēriju vairošanās un dzīvotspējas veicinātājas pienā]. Proceedings of the Latvia University of Agriculture, 21 (316), 42-50 (in Latvian).
Beitane, I., Ciprovica, I. (2011). The study of added prebiotics on B group vitamins concentration during milk fermentation. AC Romanian Biotechnol. Lett., 16 (6) Supplement, 92-96.

Biedrzycka, E., Bielecka, M. (2004). Prebiotic effectiveness of fructans of different degrees of polymerization. Trends Food Sci. Technol., 15, $170-175$.

Bouhnik, Y., Attar, A., Joly, F. A., Riottot, M., Dyard, F., Flourie, B. (2004). Lactulose ingestion increases faecal bifidobacterial counts: A randomised double-blind study in healthy humans. Eur. J. Clin. Nutr., 58, 462-466.

Bouhnik, Y., Raskine, L., Champion, K., Andrieux, C., Penven, S., Jacobs, H., Simoneau, G. (2007). Prolonged administration of low-dose inulin stimulates the growth of bifidobacteria in humans. Nutr. Res., 27, 187-193.

Crittenden, R. G., Martinez, N. R., Playne, M. J. (2003). Synthesis and utilization of folate by yoghurt starter cultures and probiotic bacteria. Int. J. Food Microbiol., 80, 217-222.

Dong, P., Yang, Y., Wang, W.-P. (2010). The role of intestinal bifidobacteria on immune system development in young rats. Early Hum. Devel., 86, $51-58$.

He, T., Priebe, M.G., Zhong, Y., Huang, C., Harmsen, H. J. M., Raangs, G. C., Antoine, J. M., Welling, G. W., Vonk, R. J. (2007). Effects of yogurt and bifidobacteria supplementation on the colonic microbiota in lactose-intolerant subjects. J. Appl. Microbiol., 104, 595-604.

Herrera-Camacho, I., Rosas-Murrieta, N. H., Rojo-Dominguez, A., Millan, L., Reyes-Leyva, J., Santos-Lopez, G., Suarez-Rendueles, P. (2007). Biochemical characterization and structural prediction of novel cytosolic leucyl amino-peptidase of the M17 family from Schizosaccharomyces pombe. FEBS Journal, 274, 6228-6240.

Holzapfel, W. H., Schillinger, U. (2002). Introduction to pre- and probiotics. Food Res. Int., 35, 109-116.

Jiang, T., Mustapha, A., Savaiano, D. A. (1996). Improvement of lactose digestion in humans by ingestion of unfermented milk containing Bifidobacterium longum. J. Dairy Sci., 79, 750-757.

Kandler, O. (1983). Carbohydrate metabolism in lactic acid bacteria. Antonie van Leeuwenhoek, 49, 209-224.

Kumar, M., Nagpal, R., Kumar, R., Hemalatha, R., Verma, V., Kumar, A., Chakraborty, Ch., Singh, B., Marotta, F., Jain, Sh., Yadav, H. (2012). Cholesterol-Lowering Probiotics as Potential Biotherapeutics for Metabolic Diseases. Experimental Diabetes Research. Jan 2012, pp. 1-14. DOI: $10.1155 / 2012 / 902917$.

Liu, S. Q., Holland, R., Crow, V. L. (2004). Esters and their biosynthesis in fermented dairy products: A review. Int. Dairy J., 14, 923-945.

Martinez-Villaluenga, C., Gomez, R. (2007). Characterization of bifidobacteria as starters in fermented milk containing raffinose family of oligosaccharides from lupina as prebiotics. Int. Dairy J., 17 (2), pp. 116-122.

Matteuzi, D., Crociani, F., Enaldi, O. (1978). Amino acids produced by bifidobacteria and some clostridia. Ann. Microbiol., 129, 175-182.

Oberman, H., Libudzisz, L. (1998). Fermented milks. In: Wood, B. J. B. (Ed.). Microbiology of Fermented Foods (pp. 308-351). London: Blackie Academic\&Professional.

Oliszewski, R., Medina, R. B., Gonzalez, S. N., Perez Chaia, A. B. (2007). Esterase activities of indigenous lactic acid bacteria from Argentinean goats' milk and cheeses. Food Chem., 101, 1446-1450.

Oliveira, R. P. D. S., Florence, A. C. R., Perego, P., De Oliveira, M. N., Converti, A. (2011). Use of lactulose as prebiotic and its influence on the growth, acidification profile and viable counts of different probiotics in fermented skim milk. Int. J. Food Microbiol., 145, 22-27.

Palframan, R. J., Gibson, G. R., Rastall, R. A. (2002). Effect of pH and dose on the growth of gut bacteria on prebiotic carbohydrates in vitro. Anaerobe, 8, 287-292.

Parvez, S., Malik, K. A., Ah Kang, S., Kim, H.-Y. (2006). Probiotics and their fermented food products are beneficial for health. J. Appl. Microbiol., 100, 1171-1185. 
Pereira, D. I. A., Gibson, G. R. (2002). Effect of consumption of probiotics and prebiotics on serum lipid levels in humans. Critical Rev. Biochem. Mol. Biol., 37, 259-281.

Qiao, H., Duffy, L. C., Griffiths, E., Dryja, D., Leavens, A., Rossman, J. O. N., Rich, G., Riepenhoff-Talty, M., Locniskar, M. (2002). Immune responses in rhesus rotavirus-challenged BALB/c mice treated with bifidobacteria and prebiotic supplements. Pediatric Res., 51, 750-755.

Rastall, R. A., Maitin, V. (2002). Prebiotics and synbiotics: Towards the next generation. Curr. Opinion Biotechnol., 13, 490-496.

Rhimi, M., Boisson, A., Dejob, M., Boudebouze, S., Maguin, E., Haser, R., Aghajari, N. (2010). Efficient bioconversion of lactose in milk and whey: Immobilization and biochemical characterization of a $\beta$-galactosidase from the dairy Streptococcus thermophilus LMD9 strain. Res. Microbiol., $161,515-525$.

Russell, D. A., Ross, R. P., Fitzgerald, G. F., Stanton, C. (2011). Metabolic activities and probiotic potential of bifidobacteria. Int. J. Food Microbiol., 149, 88-105.

Saarela, M., Hallamaa, K., Mattila-Sandholm, T., Mättö, J. (2003). The effect of lactose derivatives lactulose, lactitol and lactobionic acid on the functional and technological properties of potentially probiotic Lactobacillus strains. Int. Dairy J., 13, 291-302.

Semjonovs, P., Marauska, R., Linde, R., Grube, M., Zikmanis, P., Bekers, M. (2004). Development of Bifidobacterium lactis Bb12 on $\beta-(2,6)$-Linked Fructan-Containing Substrate. Eng. Life Sci., 4 (5), 433-437.
Sgorbati, B., Biavati, B., Palenzona, D. (1995). The genus Bifidobacterium. In: Wood B. J. B., Holzapfel, W. H. (eds.). The Genera of Lactic Acid Bacteria (pp. 279-303). Glasgow: Chapman\&Hall.

Simova, E., Simov, Z., Beshkova, D., Frengova, G., Dimitrov, Z., Spasov, Z. (2006). Amino acid profiles of lactic acid bacteria, isolated from kefir grains and kefir starter made from them. Int. J. Food Microbiol., 107, $112-123$.

Szilagyi, A., Rivard, J., Fokeeff, K. (2001). Improved parametrs of lactose maldigestion using lactulose. Digest. Dis. Sci., 46 (7), 1509-1519.

Tuohy, K. M., Rouzaud, G. C. M., Bruck, W. M., Gibson, G. R. (2005). Modulation of the human gut microflora towards improved health using prebiotics - assessment of efficacy. Curr. Pharm. Design, 11, 75-90.

Vesa, T. H., Marteau, P., Korpela, R. (2000). Lactose intolerance. J. Amer. Coll. Nutr., 19, 165S-175S.

De Vrese, M., Schrezenmeir, J. (2001) Pro and prebiotics. Innov. Food Technol., May/June, 49-55.

Walstra, P., Wouters, J. T. M., Geurts, T. J. (2006). Dairy Science and Technology. Boca Raton: CRC / Taylor \& Francis. 782 pp.

Xiao, J. Z., Kondo, S., Takahashi, N., Miyaji, K., Oshida, K., Hiramatsu, A., Iwatsuki, K., Kokubo, S., Hosono, A. (2003). Effects of milk products fermented by Bifidobacterium longum on blood lipids in rats and healthy adult male volunteers. J. Dairy Sci., 86 (7), 2452-2461.

Ziarno, M., Sekul, E., Lafraya, A. A. (2007). Cholesterol assimilation by commercial yoghurt starter cultures. Acta Scientiarum Polonorum Technologia Alimentaria, 6, 83-94.

13 September 2012

\section{Bifidobacterium lactis RAUDZĒTU PIENA PRODUKTU UZTURVĒRTĪBAS PAAUGSTINĀŠANA}

Bifidobaktērijas ir vienas no nozīmīgākajām un plašāk lietotajām probiotikām piena produktu ražošanā, pateicoties to daudzveidīgajai labvēlīgajai ietekmei. Bifidobaktērijām vairojoties, substrātā tiek izdalīti šādi enzīmi: aminopeptidāzes, galaktozidāzes, esterāzes, kuru darbības rezultātā iegūst raudzētu piena produktu ar paaugstinātu aminoskābju, zemāku holesterīna un laktozes saturu. Bifidobaktēriju enzimātiskā aktivitāte pienā nosaka raudzētā produkta uzturvērtību. Tā kā dažādu enzīmu aktivitāte ir atškirīga, tad, pievienojot prebiotikas, ir iespējams veicināt enzīmu darbību, tādējādi palielinot vai samazinot atsevišķu uzturvielu saturu gatavajā produktā. Pievienojot pienam 2\% laktulozes, tika panākts būtisks $(P<0.05)$ atsevišḳu aminoskābju (leicīna, fenilalanīna, lizīna un arginīna) satura pieaugums raudzētajā produktā. Prebiotiku klātbūtne nodrošināja holesterīna satura samazinājumu par $35 \%$ un laktozes satura samazinājumu par $31 \%$ piena fermentēšanā. Pētījuma rezultāti pierādīja, ka bifidobaktēriju enzimātisko aktivitāti ir iespējams veicināt, pievienojot noteiktās koncentrācijas laktulozi un inulīnu, paaugstinot raudzēto piena produktu uzturvērtību. 